\title{
Relationship Between EGFR Expression in Oral Cancer Cell Lines and Cetuximab Antibody-dependent Cell-mediated Cytotoxicity
}

\author{
HIROSHI NAKAMURA ${ }^{1}$, SHIGEHIRO TAMAKI ${ }^{1}$, TAKAHIRO YAGYUU ${ }^{1}$, \\ NOBUHIRO YAMAKAWA ${ }^{1}$, KATSUHIKO HATAKE ${ }^{2}$ and TADAAKI KIRITA ${ }^{1}$ \\ ${ }^{1}$ Department of Oral and Maxillofacial Surgery, Nara Medical University, Nara, Japan; \\ ${ }^{2}$ Department of Legal Medicine, Nara Medical University, Nara, Japan
}

\begin{abstract}
Background/Aim: Cetuximab treatment targets the epidermal growth factor receptor (EGFR) overexpressed in oral cancer. This study aimed to investigate the antitumour activity of cetuximab against oral cancer cell lines with respect to antibody-dependent cell-mediated cytotoxicity $(A D C C)$, and determine the correlation between ADCC and EGFR expression. Materials and Methods: EGFR expression in oral cancer cells was measured by quantitative flow cytometric analysis and immunohistochemistry. ADCC activity was measured by 4-h calcein release assays. Results: Cetuximab-mediated ADCC against oral cancer cells was detectable at a concentration of $0.1 \mu \mathrm{g} / \mathrm{ml}$. A high correlation was observed between the number of EGFR molecules on the surface of oral cancer cells and ADCC (correlation coefficient: 0.847; $p=0.032$ ). Conclusion: $A D C C$ is an important mechanism underlying the therapeutic effect of cetuximab, and EGFR expression in tumour cells might serve as a predictive marker to evaluate the effect of cetuximab treatment.
\end{abstract}

Head and neck squamous cell carcinoma (HNSCC) is the sixth most frequent type of cancer worldwide and oral squamous cell carcinoma (OSCC) represents approximately $90 \%$ of all oral neoplasms (1). Despite great therapeutic advances made over the past few decades, morbidity remains high (2) and the fiveyear survival rate for oral cancer has only moderately improved (3). Therefore, more specific, effective, and less toxic therapies are required for this disease. Epidermal growth factor receptor (EGFR) is a member of the HER tyrosine kinase receptor

Correspondence to: Hiroshi Nakamura, Department of Oral and Maxillofacial Surgery, Nara Medical University, 840 Shijo-cho, Kashihara, Nara 634-8521, Japan. Tel: +81 744223051, Fax: +81 744224121, e-mail: nakahiro@naramed-u.ac.jp

Key Words: Antibody-dependent cell-mediated cytotoxicity, cetuximab, EGFR natural killer cells, oral cancer. family, which participates in cell death and proliferation, cell motility, angiogenesis, and extracellular matrix composition (4). It is commonly overexpressed in OSCC and is frequently correlated with an aggressive phenotype, poor prognosis, and resistance to anti-cancer therapy (5). Therefore, EGFR is an attractive molecular target for anticancer strategies and antiEGFR monoclonal antibodies (mAbs), such as cetuximab and panitumumab; small molecule tyrosine kinase inhibitors, such as gefitinib and erlotinib, that target this receptor, have already been developed (6). However, only cetuximab is currently approved for the therapy of advanced OSCC (7). Cetuximab therapy is effective for the treatment of recurrent and metastatic OSCC, as a first-line treatment in combination with platinumbased chemotherapy $(8,9)$ and as a second-line therapy for patients with platinum-resistant disease; however, the ability of EGFR expression to predict patient response to EGFR-targeted therapeutic agents has not been sufficiently investigated, and responses are limited to $10-20 \%$ of patients (10).

Cetuximab, a recombinant human-murine chimeric $\mathrm{mAb}$, specifically binds to EGFR on the cell surface and interferes with downstream signal transduction (11). Consequently, it inhibits tumour cell proliferation, invasion, metastasis, and angiogenesis, and promotes tumour cell apoptosis $(12,13)$. Moreover, cetuximab can potentially induce immunologic anti-tumour effects, called antibody-dependent cell-mediated cytotoxicity (ADCC), since it consists of a human IgG1 backbone (14). ADCC is triggered following binding of the antibody $\mathrm{Fc}$ region to the $\mathrm{CD} 16 \mathrm{Fc}$ receptor on effector immune cells such as natural killer (NK) cells, macrophages, and granulocytes. In general, NK cells are the major effector cells that mediate ADCC (15). Although occurrence of ADCC in oral cancer cell lines in vitro has been demonstrated in previous studies $(16,17)$, only few have investigated its correlation with EGFR expression.

In this study, we investigated the biological activity of cetuximab against oral cancer cell lines, regarding ADCC activity, and determined whether ADCC correlates with the EGFR expression levels on the cell surface. 


\section{Materials and Methods}

Cell lines and culture. Six oral cancer cell lines (Ca9-22, SAS, SKN-3, HSC-4, OSC-19, and Ho-1-u-1) were used in this study; all were obtained from the JCRB Cell Bank (Osaka Japan), cultured in DMEM supplemented with $10 \%$ heat-inactivated FBS, $100 \mathrm{U} / \mathrm{ml}$ penicillin, and $100 \mathrm{mg} / \mathrm{ml}$ streptomycin, and incubated at $37^{\circ} \mathrm{C}$ with $5 \% \mathrm{CO}_{2}$.

Flow cytometric analysis. To analyse surface markers on effector cells, cells were stained with FITC-, PE-, or APC-conjugated mAbs against CD3, CD16, CD56, and NKG2D (Miltenyi Biotec, Bergisch Gladbach, Germany). Cells were then washed and analysed using a flow cytometer (Cytomics FC500, Beckman Coulter, Brea, CA, USA). Cell surface EGFR expression was quantified by the Quantitative Immunofluorescence Indirect assay (QIFIKIT, Dako, Copenhagen, Denmark). This kit is composed of a series of calibration beads coated with different, but well-defined, quantities of mouse mAb molecules. Briefly, 105 cells were incubated with the anti-EGFR antibodies (clone 528, Santa Cruz, CA, USA) and after three washes with PBS, they were incubated with FITC-conjugated secondary antibodies. Calibration beads of the kit were also incubated with the same secondary antibodies. The samples were analysed by flow cytometry (Cytomics FC500, Beckman Coulter). The number of EGFR molecules on the surface of oral cancer cells was calculated based on the equation of calibration curve constructed using the mean fluorescence intensity of calibration beads. Data acquisition and analysis, including regression of the calibration curve and calculation of antigen quantity, were performed according to the manufacturer's instructions.

Immunohistochemistry (IHC). Paraffin-embedded cell blocks were prepared from each oral cancer cell line, which was fixed in $4 \%$ paraformaldehyde. EGFR expression was examined by immunohistochemistry using the Dako EGFR PharmDx kit (Dako). The staining procedures were carried out according to the manufacturer's instructions.

\section{Cell processing}

Preparation of the FN-CH296 (RetroNectin $\left.{ }^{\circledR}\right)$-stimulated T (RN-T) cells. FN-CH296 (RetroNectin ${ }^{\circledR}$, Takara Bio, Siga, Japan)stimulated T (RN-T) cells were prepared as previously described (18). Briefly, peripheral blood mononuclear cells (PBMCs; C12907, PromoCell, Heidelberg, Germany) were re-suspended in GTT551 culture medium (Takara Bio) supplemented with $0.5 \%$ heatinactivated human serum (Lonza, Basel, Switzerland) and IL-2 (Kohjin Bio, Saitama, Japan), and then transferred to a CultiLife215 bag (Takara Bio) that was pre-coated with both anti-CD3 antibody (Miltenyi Biotec) and FN-CH296 (RetroNectin ${ }^{\circledR}$, Takara Bio). On day 4 , the cells were transferred to a CultiLife Eva bag (Takara), and diluted with GT-T551 medium containing human serum $(0.5 \%)$ and IL-2 every 3 or 4 days. Cells were cultured for 2 weeks, $\gamma$ irradiated, and then used as stimulators for NK-cell expansion.

Expansion of NK cells. NK cells were expanded as previously described (19). Briefly, PBMCs (C-12907, PromoCell) were suspended in culture medium supplemented with $1 \%$ heatinactivated human serum (Lonza), OK-432 (Chugai Pharmaceutical, Tokyo, Japan), and IL-2. PBMCs were cultured for 3 weeks, adding RT-N cells as a stimulator on day 1 and 7 .
Table I. EGFR expression analysis by quantitative flow cytometry (QIFIKIT) in oral cancer cell lines.

\begin{tabular}{lc}
\hline Cell lines & $\begin{array}{c}\text { EGFR expression } \\
\text { (no. EGFR per cell) }\end{array}$ \\
\hline Ho-1-u-1 & $1.13 \times 10^{5}$ \\
OSC-19 & $3.26 \times 10^{5}$ \\
HSC-4 & $4.24 \times 10^{5}$ \\
SKN-3 & $4.39 \times 10^{5}$ \\
SAS & $5.55 \times 10^{5}$ \\
Ca9-22 & $6.95 \times 10^{5}$ \\
\hline
\end{tabular}

Growth inhibition assay. Cell viability was assessed by the CalceinAM method. Cells were plated at $10^{4}$ cells/well in a 96-well plate. Following an overnight incubation, cetuximab was added at various concentrations (from 1 to $100 \mu \mathrm{g} / \mathrm{ml}$ ). After $4 \mathrm{~h}$, Calcein-AM (Dojindo, Kumamoto, Japan) was added to each well, followed by incubation for $30 \mathrm{~min}$ at $37^{\circ} \mathrm{C}$; the fluorescence intensity was then measured using a fluorescence microplate reader (Berthold, Mithras LB940; excitation $485 \mathrm{~nm}$, emission $538 \mathrm{~nm}$ ). Cell viability was evaluated based on the fluorescence intensity of target cells. Each experiment was performed in triplicate for each drug concentration and independently three times.

ADCC assay. ADCC was examined by performing a Calcein-AM (Dojindo) release assay. NK cells were used as the effectors and oral cancer cells (Ca9-22, SAS, SKN-3, HSC-4, OSC-19, and Ho-1-u-1) were used as targets. After the target cells were labelled with Calcein-AM (Dojindo) for $60 \mathrm{~min}$, target $\left(10^{4}\right.$ cells/well) and effector cells at various effector:target (E:T) ratios were co-incubated in a 96well U-bottomed plate in triplicate for $4 \mathrm{~h}$ at $37^{\circ} \mathrm{C}$ with or without cetuximab. Next, the supernatants were analysed using a fluorescence microplate reader (Berthold, Mithras LB940; excitation $485 \mathrm{~nm}$, emission $538 \mathrm{~nm}$ ) to measure calcein release (cell death). For maximal release, the target cells were lysed with $0.1 \%$ triton $\mathrm{X}$ 100. The cytotoxicity and ADCC percentages were calculated using the following formulas: cytotoxicity $(\%)=[($ experimental fluorescence - spontaneous fluorescence)/(maximum fluorescence - spontaneous fluorescence)] $\times 100 ; \operatorname{ADCC}(\%)=$ cytotoxicity $(\%$, with cetuximab) - cytotoxicity ( $\%$, without cetuximab).

Statistical analysis. The correlation between the EGFR expression level and cetuximab-mediated ADCC was evaluated by univariate regression analysis. $p$-Values $<0.05$ were considered to indicate statistically significant results.

\section{Results}

Efficient expansion of NK cells. PBMCs were cultured for 21 days. The percentage of $\mathrm{CD}^{-} / \mathrm{CD}^{2} 6^{+} \mathrm{NK}$ cells increased from an initial $6.3 \%$ to $93.2 \%$ on day 21 of cell culture (372fold). The cell-surface expression levels of CD16 and NKG2D, functional markers of $\mathrm{NK}$ cells, were then examined. The proportions of NKG2D- and CD16-positive cells increased from initial $19.6 \%$ and $6.3 \%$ to $99.8 \%$ and $37.1 \%$ on day 21 of cell culture, respectively (Figure 1). 


\section{Day 0}



CD3 - PE

Day 0

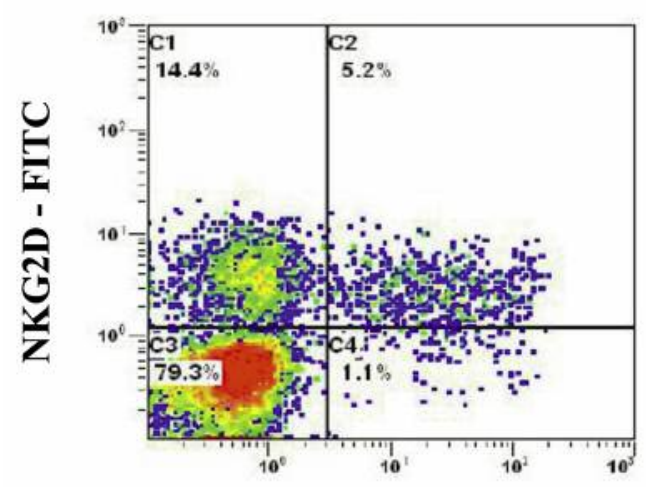

CD16 - APC
Day 21



Day 21

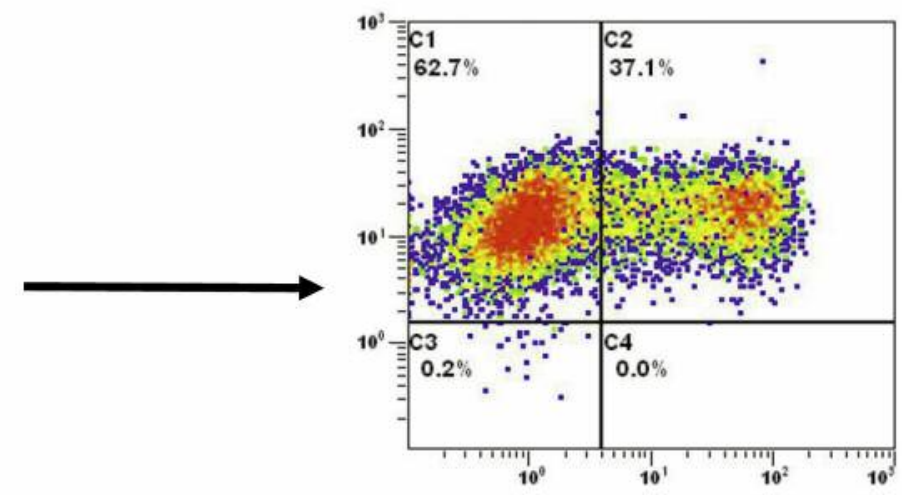

CD16 - APC

Figure 1. Expansion of natural killer (NK) cells. Peripheral blood mononuclear cells (PBMCs) were stimulated with OK-432, IL-2, and RN-T cells as described in the materials and methods. The percentage of $\mathrm{CD}^{-} / \mathrm{CD} 56^{+} \mathrm{NK}$ cells increased to $93.2 \%$ on day 21 of cell culture from $6.3 \%$ at the start of culture. The NK cells were thus expanded 372-fold on day 21. The cell surface expression levels of CD16 and NKG2D, which are considered functional markers of NK cells, were examined. The percentage of NKG2D-and CD16-expressing cells increased to $99.8 \%$ and $37.1 \%$ on day 21 of cell culture from $19.6 \%$ and $6.3 \%$ at the start of culture, respectively.

Analysis of EGFR expression in oral cancer cell lines by flow cytometry and IHC. We then measured the number of EGFRs on each oral cancer cell line by quantitative flow cytometric analysis. As shown in Table I, these cell lines differed in terms of the number of EGFR molecules per cell, with $\mathrm{Ca}-22$ cells showing the highest and Ho-1-u-1 cells having the lowest EGFR expression. IHC was also performed to detect EGFR expression in oral cancer cell lines. Immunostaining demonstrated clear expression of EGFR in all oral cancer cell lines (Figure 2).

Direct growth inhibitory effect of cetuximab on oral cancer cell lines. Cetuximab did not exert a direct effect on growth inhibition in any of the cell lines examined, despite their overexpression of EGFR. Even the highest concentration of cetuximab $(100 \mu \mathrm{g} / \mathrm{ml})$ did not inhibit the growth of any of the cell lines (Figure 3).

Cetuximab-mediated ADCC against oral cancer cell lines. To determine whether cetuximab can induce ADCC against Ho1-u-1 cells, which were found to have the lowest EGFR expression in this study, we performed calcein release assays using NK cells at various E:T ratios. At higher E:T ratios (12:1 and 6:1), cetuximab mediated augmented cytotoxicity, which was greater than that observed with NK cells only (Figure 4A). We also performed calcein release assays using Ho-1-u-1 cells, with increasing doses of cetuximab and an $\mathrm{E}: \mathrm{T}$ ratio of $6: 1$. ADCC could be detected at a concentration 

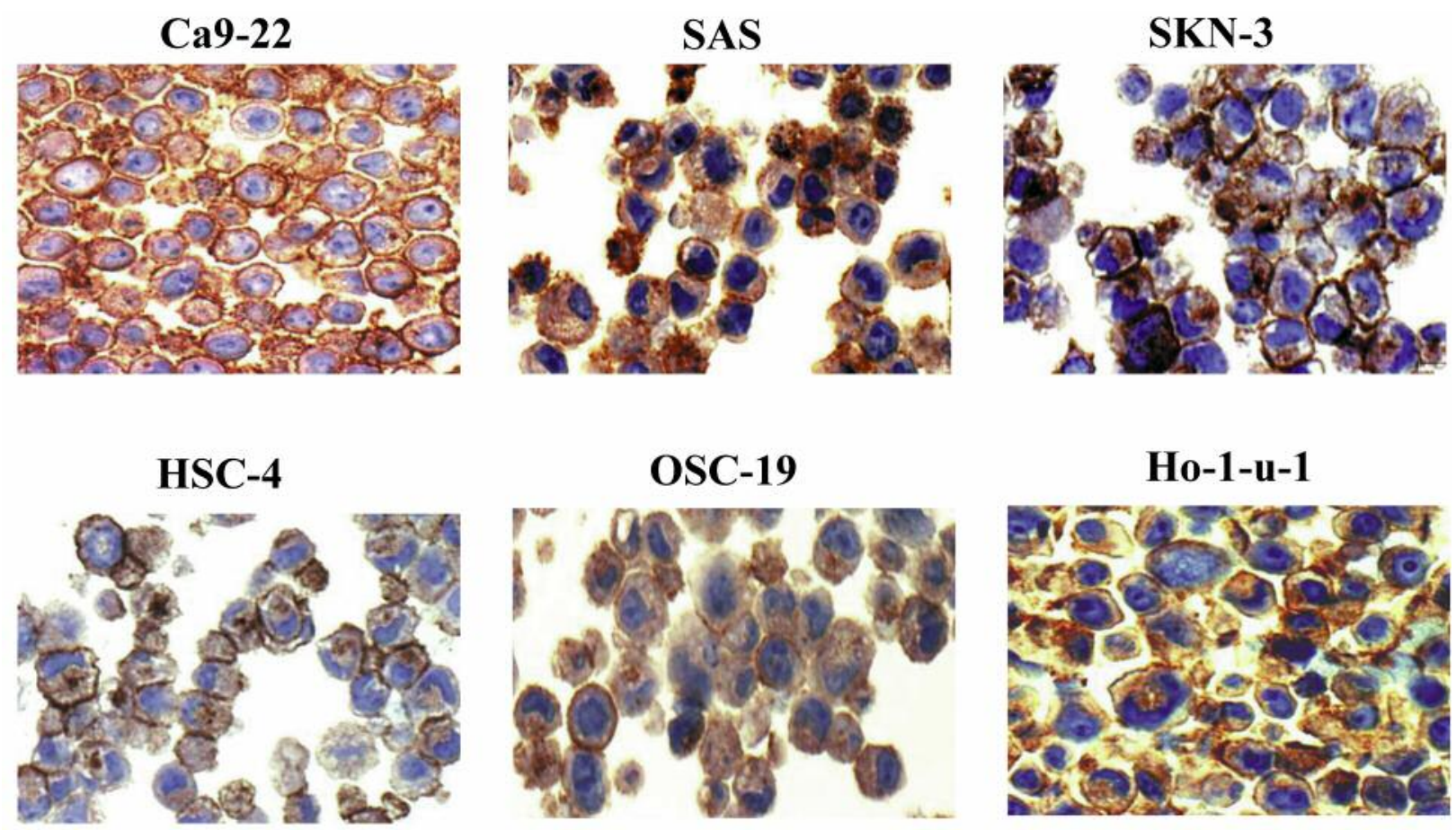

Figure 2. Immunohistochemical staining for EGFR expression in oral cancer cell lines. Immunostaining for EGFR demonstrated clear protein expression in all cell lines.

of $0.1 \mu \mathrm{g} / \mathrm{ml}$ and plateaued at $1 \mu \mathrm{g} / \mathrm{ml}$ (Figure 4B). These data suggest that cetuximab concentrations exceeding $1 \mu \mathrm{g} / \mathrm{ml}$ are enough for maximal ADCC.

Next, to evaluate the correlation between the cetuximabmediated ADCC and EGFR expression, we assessed ADCC towards oral cancer cell lines with various EGFR levels (cetuximab concentration, $1 \mu \mathrm{g} / \mathrm{ml}$ ). ADCC was detected in all oral cancer cell lines at various degrees, and the highest ADCC for each cell line was detected at an E:T ratio of 12:1 (Figure 5). Under this condition, a marked correlation between ADCC and the number of EGFR molecules on the cell surface was observed (correlation coefficient, $\mathrm{R}=0.847 ; p=0.032$; Figure 6).

\section{Discussion}

Cetuximab was developed as a human-murine chimeric antibody derived from the murine antibody (M225), which binds specifically to the ligand-binding domain of EGFR (20). The primary mechanism of action of M225 is the competitive antagonism of EGFR. Blocking the interaction between EGFR and its endogenous ligand, and thus inhibiting the downstream signal transduction cascade, can achieve anti-tumour effects, cell-cycle arrest, the induction of apoptosis, the inhibition of angiogenesis, the inhibition of metastasis, internalization and downregulation of the EGFR, and enhanced sensitivity to radiochemotherapy (21).
Compared to these direct inhibitory effects on EGFR signalling, immunological effects of M225, such as ADCC, were reported to be slight $(20,22)$. Unlike M225, cetuximab includes a human IgG1 constant region, and chimeric IgG1 antibodies can effectively elicit ADCC mediated by effector cells (23). Although chimeric IgG1 antibodies have been reported to be able to activate ADCC in effector cells (23), the effect of cetuximab-mediated ADCC on oral cancer remains to be clarified; only little information on this topic has been reported, compared to that regarding the direct inhibitory effect on EGFR signalling.

In this study, cetuximab-mediated ADCC against oral cancer cell lines was detected at a low antibody concentration, even though a high concentration of cetuximab did not inhibit cell proliferation. Maximal ADCC was observed at a concentration of $1.0 \mu \mathrm{g} / \mathrm{ml}$. In a phase I study of cetuximab, using a schedule comprising of an initial dose of $400 \mathrm{mg} / \mathrm{m}^{2}$, followed by a weekly maintenance dose of $250 \mathrm{mg} / \mathrm{m}^{2}$, the mean Cmax and Cmin concentrations at steady state were reported to be $157.76 \pm 30.49 \mu \mathrm{g} / \mathrm{ml}$ and $55.77 \pm 15.51 \mu \mathrm{g} / \mathrm{ml}$, respectively (24). Based on previous reports, the average plasma concentration of cetuximab in cancer patients is estimated to be within the range of 56 to $100 \mu \mathrm{g} / \mathrm{ml}$ under current clinical dosing regimens (25). However, regarding the cetuximab concentrations in tumours, the results of previous studies have been variable, 
Ca9-22



Cetuximab concentration $(\mu \mathrm{g} / \mathrm{ml})$

HSC-4

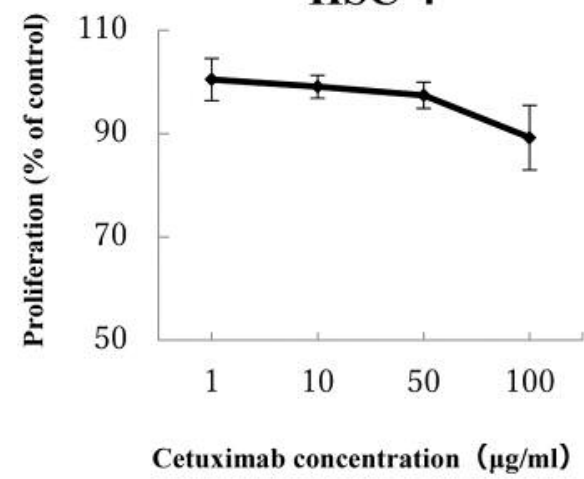

SAS

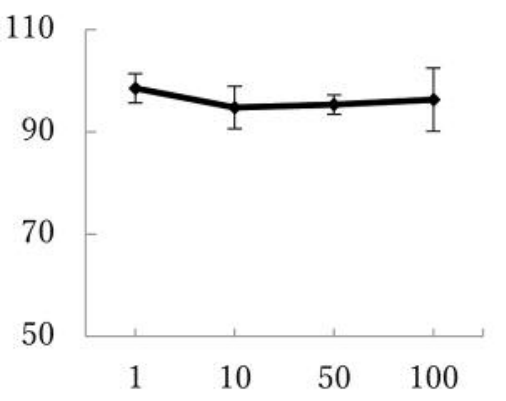

Cetuximab concentration $(\mu \mathrm{g} / \mathrm{ml})$

OSC-19

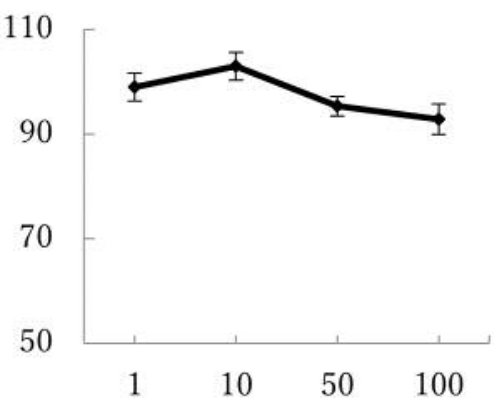

Cetuximab concentration $(\mu \mathrm{g} / \mathrm{ml})$
SKN-3

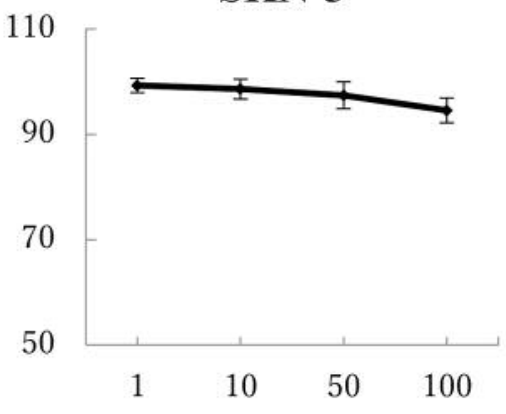

Cetuximab concentration $(\mu \mathrm{g} / \mathrm{ml})$

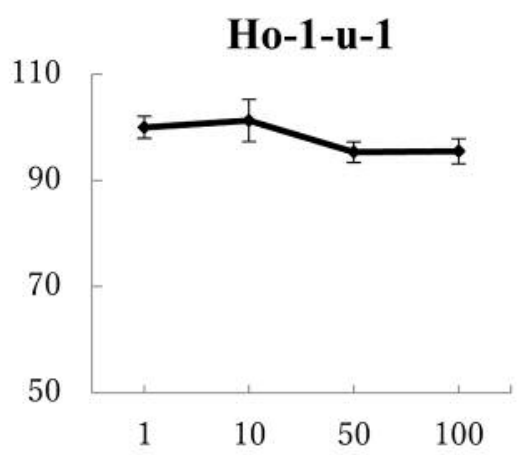

Cetuximab concentration $(\mu \mathrm{g} / \mathrm{ml})$

Figure 3. Growth inhibitory effect of cetuximab alone on oral cancer cell lines. Cells were treated with the indicated concentrations of cetuximab (1-100 $\mu \mathrm{g} / \mathrm{ml})$ and proliferation was measured by the Calcein-AM method after $4 \mathrm{~h}$.

A

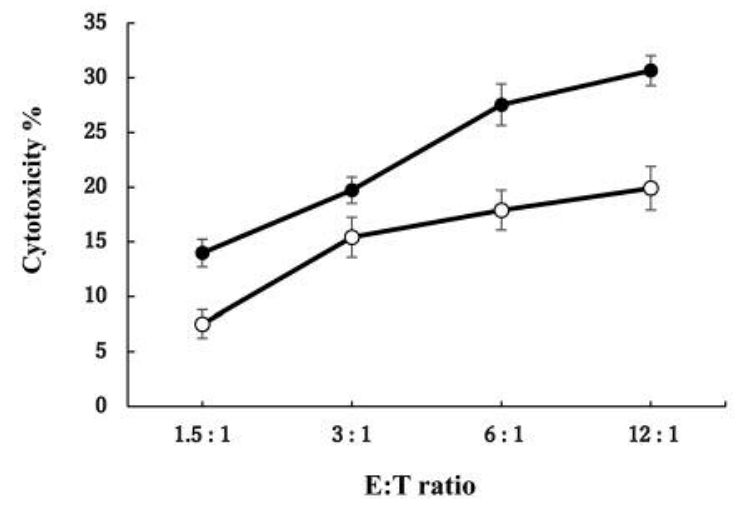

B Ho-1-u-1

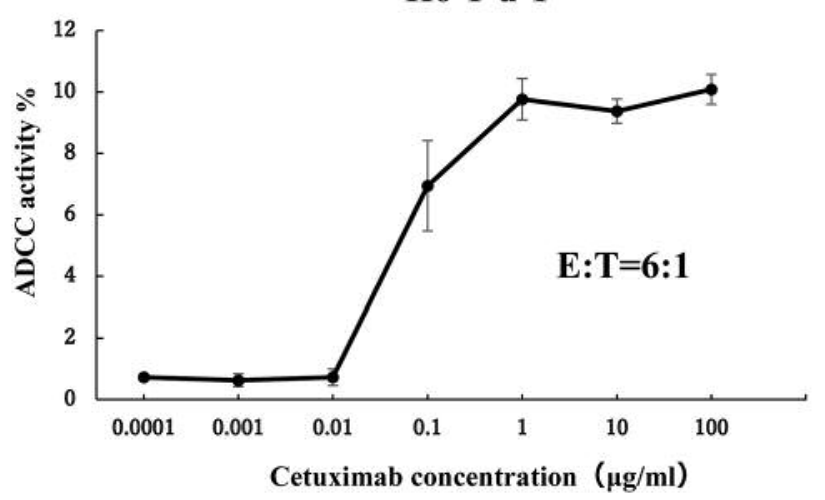

$\rightarrow \quad$ Ho-1-u-1 + NK cells + Cetuximab

- Ho-1-u-1 + NK cells

Figure 4. Cetuximab-mediated cytotoxicity against Ho-1-u-1 cells. (A) The effect of cetuximab on the survival of Ho-1-u-1 cells, the cell line expressing the lowest level of EGFR in this study, was determined. Natural killer (NK) cells, at four different effector-to-target cell (E:T) ratios, were examined for cytotoxicity in the presence or absence of cetuximab $(10 \mu \mathrm{g} / \mathrm{ml})$. (B) Concentration-dependence of cetuximab-mediated antibodydependent cell-mediated cytotoxicity (ADCC) activity against Ho-1-u-1 cells. 


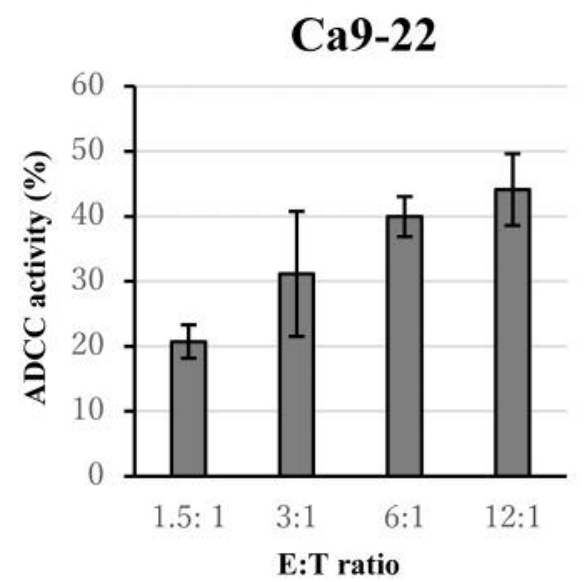

HSC-4

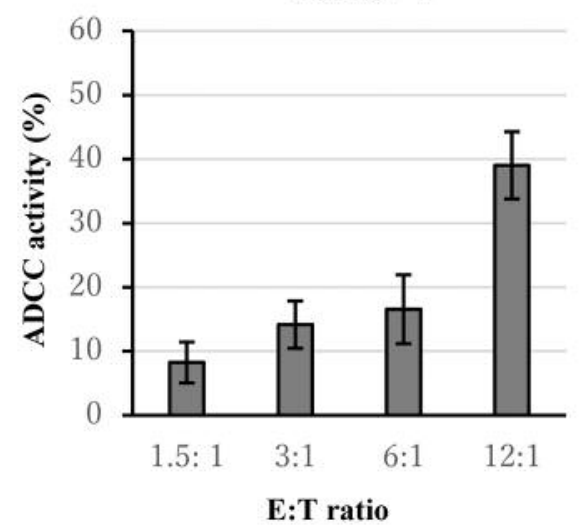

SAS

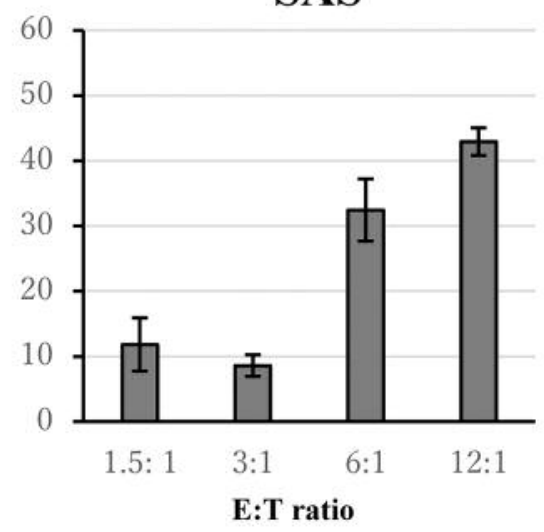

OSC-19

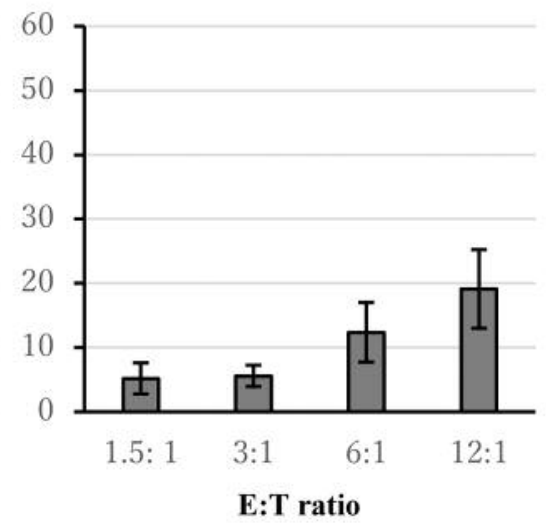

SKN-3

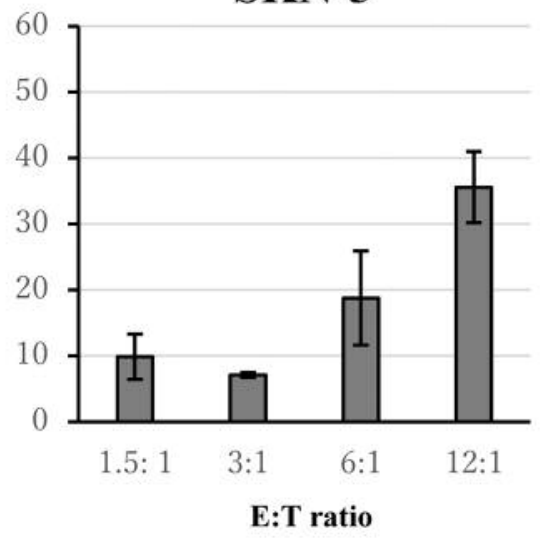

Ho-1-u-1



Figure 5. Cetuximab-mediated antibody-dependent cell-mediated cytotoxicity (ADCC) against oral cancer cell lines (cetuximab concentration, 1 $\mu$ g/ml). Cytotoxicity was assessed by performing Calcein release assays in the presence of natural killer cells (effector cells). The highest ADCC activity in each cell line was observed at an effector-to-target cell (E:T) ratio of 12:1.

indicating that levels are four-fold higher (26) to 50-100-fold lower (25) in tumour cells than in serum. A cetuximab concentration of $1.0 \mu \mathrm{g} / \mathrm{ml}$, which induced maximal ADCC in our experiments, is almost within these ranges. Therefore, maximal ADCC mediated by cetuximab could be obtained based on current clinical regimens. Moreover, the concentration of $1.0 \mu \mathrm{g} / \mathrm{ml}$ is lower than that required to obtain the maximum inhibition of growth via EGFR inhibitory mechanisms in vitro (greater than $1.25 \mu \mathrm{g} / \mathrm{ml}$ ) (27). These data suggested that ADCC can be induced effectively at a comparatively low dose and could play an important role in the therapeutic activity of cetuximab.

NK cells are considered the major effector cells related to ADCC both in physiological and therapeutic settings (28). In the present study, using activated NK cells as effector cells, cetuximab mediated-ADCC was detected in all oral cancer cell lines. However, NK cells in cancer patients are generally considered to be impaired due to many mechanisms including reduction in their numbers, imbalances in activating and inhibitory receptors, impaired activation of signalling cascades, and immunosuppressive cytokines. Kawaguchi et al. reported that conventional therapeutic mAb-mediated ADCC is impaired in advanced disease compared to that in early disease (29). Therefore, augmenting ADCC in cancer patients or those under immunosuppressive conditions may enhance the clinical efficacy of therapeutic mAbs. Removal of fucose from antibody oligosaccharides attached to $\mathrm{Asn}^{297}$ of the heavy chain (defucosylation) has been shown to significantly enhance Fc receptor binding affinity between Fc receptors on NK cells and mAbs, compared to that with conventional antibodies, hence leading to augmented $\operatorname{ADCC}(30,31)$. Thus, defucosylation technology is considered to be one of the most powerful approaches to enhance the clinical effect of therapeutic mAbs. However, there has been only one report indicating the utility of defucosylated cetuximab with respect to ADCC (32).

Previous studies had investigated the effect of EGFR expression levels on the mechanisms associated with cetuximab; however, discordant results were reported. Patel 


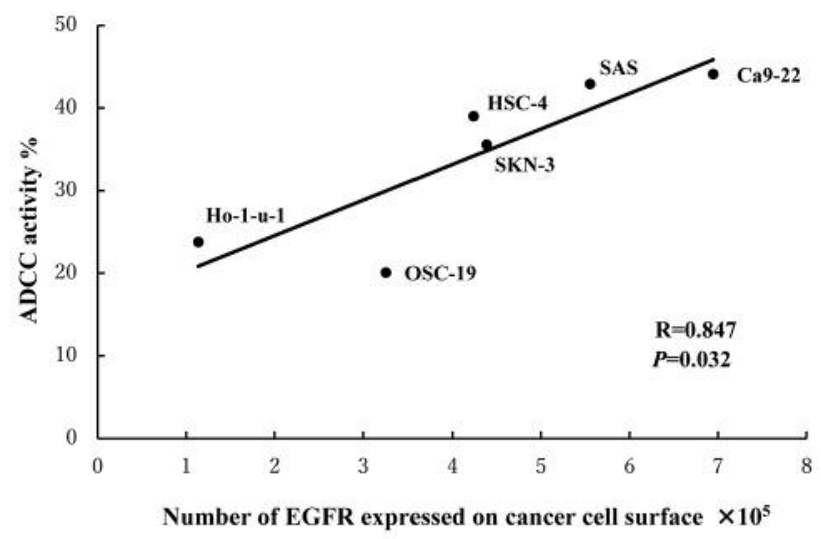

Figure 6. Correlation between EGFR expression levels cell surface and antibody-dependent cell-mediated cytotoxicity $(A D C C)$ in six oral cancer cell lines (correlation coefficient, $R=0.847, p=0.032$ ).

et al. suggested that cetuximab-elicited ADCC against a panel of various tumour cell lines depends on EGFR expression levels on the cell surface (33). On the other hand, Kurai et al. reported that ADCC against lung cancer cell lines had no linear correlation with cell surface EGFR expression (34). These reports together suggest that ADCC is affected by numerous factors. Our study showed that cetuximab-mediated ADCC is highly correlated with the number of surface EGFR molecules on oral cancer cell lines.

In conclusion, cetuximab has ADCC activity against oral cancer cells with EGFR expression, but does not exert direct effect on growth inhibition; ADCC depends on the number of EGFR surface molecules. These observations suggest ADCC as one of the important processes associated with the therapeutic effect of cetuximab and that EGFR levels on tumour cells may serve as predictive markers to evaluate the efficacy of cetuximab treatment.

\section{Conflicts of Interest}

The Authors declare that they have no conflict of interest in relation to this manuscript.

\section{Acknowledgements}

This work was partially supported by JSPS KAKENHI (Grant No. JP25870633).

\section{Authors' Contributions}

Study concept and design: H. Nakamura, S. Tamaki, T. Kirita; Acquisition of data: H. Nakamura, S. Tamaki, T. Yagyuu, N. Yamakawa; Analysis and interpretation of data: H. Nakamura, S. Tamaki, T. Yagyuu, N. Yamakawa; Drafting of the manuscript: H. Nakamura, S. Tamaki, K. Hatake; Study supervision: K. Hatake, T. Kirita.

\section{References}

1 Zhao X, Sun S, Zeng X and Cui L: Expression profiles analysis identifies a novel three-mRNA signature to predict overall survival in oral squamous cell carcinoma. Am J Cancer Res 8 : 450-461, 2018. PMID: 29637000.

2 Jemal A, Bray F, Center MM, Ferlay J, Ward E and Forman D: Global cancer statistics. CA Cancer J Clin 61: 69-90, 2011. PMID: 21296855, DOI: 10.3322/caac.20107

3 Siegel RL, Miller KD and Jemal A: Cancer statistics, 2015. CA Cancer J Clin 65: 5-29, 2015. PMID: 25559415, DOI: 10.3322/ caac. 21254

4 Janne PA, Taffaro ML, Salgia R and Johnson BE: Inhibition of epidermal growth factor receptor signalling in malignant pleural mesothelioma. Cancer Res 62: 5242-5247, 2002. PMID: 12234991.

5 Ang KK, Berkey BA, Tu X, Zhang HZ, Katz R, Hammond EH, $\mathrm{Fu} \mathrm{KK}$ and Milas L: Impact of epidermal growth factor receptor expression on survival and pattern of relapse in patients with advanced head and neck carcinoma. Cancer Res 62: 7350-7356, 2002. PMID: 12499279.

6 Mahipal A, Kothari N and Gupta S: Epidermal growth factor receptor inhibitors: coming of age. Cancer Control 21: 74-79, 2014. PMID: 24357745, DOI: $10.1177 / 107327481402100111$

7 Loeffler-Ragg J, Schwentner I, Sprinzl GM and Zwierzina H: EGFR inhibition as a therapy for head and neck squamous cell carcinoma. Expert Opin Investig Drugs 17: 1517-1531, 2008. PMID: 18808311, DOI: 10.1517/13543784.17.10.1517

8 Bourhis J, Rivera F, Mesia R, Awada A, Geoffrois L, Borel C, Humblet Y, Lopez-Pousa A, Hitt R, Vega Villegas ME, Duck L, Rosine D, Amellal N, Schueler A and Harstrick A: Phase I/II study of cetuximab in combination with cisplatin or carboplatin and fluorouracil in patients with recurrent or metastatic squamous cell carcinoma of the head and neck. J Clin Oncol 24: 2866-2872, 2006. PMID: 16717293, DOI: 10.1200/JCO.2005. 04.3547

9 Vermorken JB, Mesia R, Rivera F, Remenar E, Kawecki A, Rottey S, Erfan J, Zabolotnyy D, Kienzer HR, Cupissol D, Peyrade F, Benasso M, Vynnychenko I, De Raucourt D, Bokemeyer C, Schueler A, Amellal N and Hitt R: Platinum-based chemotherapy plus cetuximab in head and neck cancer. N Engl J Med 359: 11161127, 2008. PMID: 18784101, DOI: 10.1056/NEJMoa0802656

10 Bonner JA, Harari PM, Giralt J, Azarnia N, Shin DM, Cohen RB, Jones CU, Sur R, Raben D, Jassem J, Ove R, Kies MS, Baselga J, Youssoufian H, Amellal N, Rowinsky EK and Ang KK: Radiotherapy plus cetuximab for squamous-cell carcinoma of the head and neck. N Engl J Med 354: 567-578, 2006. PMID: 16467544, DOI: 10.1056/NEJMoa053422

$11 \mathrm{Li} \mathrm{S}$, Schmitz KR, Jeffrey PD, Wiltzius JJ, Kussie P and Ferguson KM: Structural basis for inhibition of the epidermal growth factor receptor by cetuximab. Cancer Cell 7: 301-311, 2005. PMID: 15837620, DOI: 10.1016/j.ccr.2005.03.003

12 Huether A, Höpfner M, Baradari V, Schuppan D and Scherübl H: EGFR blockade by cetuximab alone or as combination therapy for growth control of hepatocellular cancer. Biochem Pharmacol 70: 1568-1578, 2005. PMID: 16226226, DOI: 10.1016/j.bcp.2005.09.007

13 Troiani T, Zappavigna S, Martinelli E, Addeo SR, Stiuso P, Ciardiello $\mathrm{F}$ and Caraglia M: Optimizing treatment of metastatic colorectal cancer patients with anti-EGFR antibodies: Overcoming the mechanisms of cancer cell resistance. Expert Opin Biol Ther 13: 241255, 2013. PMID: 23281932, DOI: 10.1517/14712598.2012.756469 
14 Naramura M, Gillies SD, Mendelsohn J, Reisfeld RA and Mueller BM: Therapeutic potential of chimeric and murine anti(epidermal growth factor receptor) antibodies in a metastasis model for human melanoma. Cancer Immunol Immunother 37: 343-349, 1993. PMID: 8402738.

15 Sulica A, Morel P, Meters D and Herberman RB: Ig-binding receptors on human NK cells as effector and regulatory surface molecules. Int Rev Immunol 20: 371-414, 2001. PMID: 11878510, DOI: 10.3109/08830180109054414

16 Luedke E, Jaime-Ramirez AC, Bhave N, Roda J, Choudhary MM, Kumar B, Teknos TN and Carson WE 3rd: Cetuximab therapy in head and neck cancer: Immune modulation with interleukin-12 and other natural killer cell activating cytokines. Surgery 152: 431-440, 2012. PMID: 22770960, DOI: 10.1016/j.surg.2012.05.035

17 Taylor RJ, Saloura V, Jain A, Goloubeva O, Wong S, Kronsberg S, Nagilla M, Silpino L, de Souza J, Seiwert T, Vokes E, Villaflor V and Cohen EE: Ex vivo antibody-dependent cellular cytotoxicity inducibility predicts efficacy of cetuximab. Cancer Immunol Res 3: 567-574, 2015. PMID: 25769300, DOI: 10.1158/2326-6066.CIR-14-0188

18 Ishikawa T, Kokura S, Enoki T, Sakamoto N, Okayama T, Ideno M, Mineno J, Uno K, Yoshida N, Kamada K, Katada K, Uchiyama K, Handa O, Takagi T, Konishi H, Yagi N, Naito Y, Itoh $\mathrm{Y}$ and Yoshikawa T: Phase I clinical trial of fibronectin CH296-stimulated $\mathrm{T}$ cell therapy in patients with advanced cancer. PLoS One 9: e83786, 2014. PMID: 24497917, DOI: 10.1371/journal.pone.0083786

19 Sakamoto N, Ishikawa T, Kokura S, Okayama T, Oka K, Ideno M, Sakai F, Kato A, Tanabe M, Enoki T, Mineno J, Naito Y, Itoh $\mathrm{Y}$ and Yoshikawa T: Phase I clinical trial of autologous NK cell therapy using novel expansion method in patients with advanced digestive cancer. J Transl Med 13: 277, 2015. PMID: 26303618, DOI: 10.1186/s12967-015-0632-8

20 BleekerWK, Lammerts van Bueren JJ, van Ojik HH, Gerritsen AF, Pluyter M, Houtkamp M, Halk E, Goldstein J, Schuurman J, van Dijk MA, van de Winkel JG and Parren PW: Dual mode of action of a human anti-epidermal growth factor receptor monoclonal antibody for cancer therapy. J Immunol 173: 46994707, 2004. PMID: 15383606.

21 Mendelsohn J: Epidermal growth factor receptor as a target for therapy with antireceptor monoclonal antibodies. J Natl Cancer Inst Monogr 13: 125-131, 1992. PMID: 11350723.

22 Fan Z, Masui H, Altas I and Mendelsohn J: Blockade of epidermal growth factor receptor function by bivalent and monovalent fragments of 225 anti-epidermal growth factor receptor monoclonal antibodies. Cancer Res 53: 4322-4328, 1993. PMID: 8364927.

23 Steplewski Z, Sun LK, Shearman CW, Ghrayeb J, Daddona P and Koprowski H: Biological activity of human-mouse IgG1, $\mathrm{IgG} 2$, IgG3, and IgG4 chimeric monoclonal antibodies with antitumor specificity. Proc Natl Acad Sci USA 85: 4852-4856, 1988. PMID: 3387441.

24 Baselga J, Pfister D, Cooper MR, Cohen R, Burtness B, Bos M, D'Andrea G, Seidman A, Norton L, Gunnett K, Falcey J, Anderson V, Waksal H and Mendelsohn J: Phase I studies of anti-epidermal growth factor receptor chimeric antibody C225 alone and in combination with cisplatin. J Clin Oncol 18: 904914, 2000. PMID: 10673534, DOI: 10.1200/JCO.2000.18.4.904

25 Luo FR, Yang Z, Dong H, Camuso A, McGlinchey Y, Fager K, Flefleh C, Kan D, Inigo I, Castaneda S, Rose WC, Kramer RA,
Wild R and Lee FY: Correlation of pharmacokinetics with the antitumor activity of cetuximab in nude mice bearing the GEO human colon carcinoma xenograft. Cancer Chemother Pharmacol 56: 455-464, 2005. PMID: 15947929, DOI: 10.1007/ s00280-005-1022-3

26 Goldenberg A, Masui H, Divgi C, Kamrath H, Pentlow K and Mendelsohn J: Imaging of human tumour xenografts with an indium-111-labelled anti-epidermal growth factor receptor monoclonal antibody. J Natl Cancer Inst 81: 1616-1625, 1989. PMID: 2795690, DOI: 10.1093/jnci/81.21.1616

27 Goldstein NI, Prewett M, Zuklys K, Rockwell P and Mendelsohn J: Biological efficacy of a chimeric antibody to the epidermal growth factor receptor in a human tumour xenograft model. Clin Cancer Res 1: 1311-1318, 1995. PMID: 9815926.

28 Yeap WH, Wong KL, Shimasaki N, Teo EC, Quek JK, Yong HX, Diong CP, Bertoletti A, Linn YC and Wong SC: CD16 is indispensable for antibody-dependent cellular cytotoxicity by human monocytes. Sci Rep 6: 34310, 2016. PMID: 27670158, DOI: $10.1038 /$ srep34310

29 Kawaguchi Y, Kono K, Mimura K, Sugai H, Akaike H and Fujii $\mathrm{H}$ : Cetuximab induce antibody-dependent cellular cytotoxicity against EGFR-expressing esophageal squamous cell carcinoma. Int J Cancer 120: 781-787, 2007. PMID: 17096332, DOI: $10.1002 / \mathrm{ijc} .22370$

30 Niwa R, Shoji-Hosaka E, Sakurada M, Shinkawa T, Uchida K, Nakamura K, Matsushima K, Ueda R, Hanai N and Shitara K: Defucosylated chimeric anti-CC chemokine receptor $4 \mathrm{IgG} 1$ with enhanced antibody-dependent cellular cytotoxicity shows potent therapeutic activity to T-cell leukaemia and lymphoma. Cancer Res 64: 2127-2133, 2004. PMID: 15026353.

31 Okazaki A, Shoji-Hosaka E, Nakamura K, Wakitani M, Uchida K, Kakita S, Tsumoto K, Kumagai I and Shitara K: Fucose depletion from human IgG1 oligosaccharide enhances binding enthalpy and association rate between IgG1 and FcgammaRIIIa. J Mol Biol 336: 1239-1249, 2004. PMID: 15037082, DOI: 10.1016/j.jmb.2004.01.007

32 Nakajima T, Okayama H, Ashizawa M, Noda M, Aoto K, Saito M, Monma T, Ohki S, Shibata M, Takenoshita S and Kono K: Augmentation of antibody-dependent cellular cytotoxicity with defucosylated monoclonal antibodies in patients with GI-tract cancer. Oncol Lett 15: 2604-2610, 2018. PMID: 29434980, DOI: 10.3892/ol.2017.7556

33 Patel D, Guo X, Ng S, Melchior M, Balderes P, Burtrum D, Persaud K, Luna X, Ludwig DL and Kang X: IgG isotype, glycosylation, and EGFR expression determine the induction of antibody-dependent cellular cytotoxicity in vitro by cetuximab. Hum Antibodies 19: 89-99, 2010. PMID: 21178280, DOI: 10.3233/HAB-2010-0232

34 Kurai J, Chikumi H, Hashimoto K, Yamaguchi K, Yamasaki A, Sako T, Touge H, Makino H, Takata M, Miyata M, Nakamoto $\mathrm{M}$, Burioka $\mathrm{N}$ and Shimizu E: Antibody-dependent cellular cytotoxicity mediated by cetuximab against lung cancer cell lines. Clin Cancer Res 13: 1552-1561, 2007. PMID: 17332301, DOI: 10.1158/1078-0432.CCR-06-1726

Received February 4, 2019

Revised February 19, 2019

Accepted February 20, 2019 